\title{
Automatic Employee Records Tracking and Validating Analytical Tool
}

\author{
G. Santhoshkumar, Velanganni, S. Robin
}

\begin{abstract}
Representative welfare exercises in India are desperately required in light of the fact that India is modern in reverse nation and the working conditions are not acceptable Indian enterprises. The specialists ate poor and uneducated and for the most part faulted being un-trust worthy and languid. Representative welfare exercises are essential for development their working conditions and their financial measures. The significance of worker welfare exercises in India has been perceived as of late by the businesses, for the legislature and by different offices. The fundamental offices occupied with representative welfare, in India incorporate (i) Central Government (ii) State Governments Employers (iii) Worker's associations and (vi) Different offices. The commitment of these offices is as clarified beneath.
\end{abstract}

Keywords: legislature, Representative welfare exercises

\section{INTRODUCTION}

Representative assumes a vital part in the modern creation of the nation. The human asset supervisors are extremely worried about the administration of individual at work .It is important to secure the collaboration of representative power keeping in mind the end goal to expand the creation and to procure higher benefits. The collaboration of representative power is conceived just when they ate completely happy with their boss and the working condition at work. Before industrialists and the business trusted that their exclusive obligation towards their workers was to pay their palatable wages and pay rates. In course of time, with the presentation of the idea of human asset administration, mental investigates persuaded them the specialists require them more critical. Not with standing giving money related advantages compassionate medications given to the representative welfare exercises advantages specialist as the administration as more prominent mechanical productivity. The human assets chiefs realize that the welfare exercises pay the decent profit over the large haul, since they contribute a consideration measure towards the wellbeing and proficiency of the specialist and towards the high spirit.[1]-[5]

Employee welfare has the accompanying targets:

Revised Manuscript Received on December 30, 2019.

G. Santhoshkumar, Assistant professor, Department Of Science \& Humanities, BharathInstitute of Higher Education and Research ,Chennai, India. .Email santhoshravi671026@gmail.com

R. Velanganni, Assistant professor, Department Of Science \& Humanities, Bharath Institute of Higher Education and Research ,Chennai, India. .Email velangannijose78516@gmail.com

S. Robin, Assistant professor, Department Of Science \& Humanities, Bharath Institute of Higher Education and Research ,Chennai, India. (i) To create best life and improve the wellness to the employee.

(ii) To make the workers strong, healthy and effective.

(iii) To enhance scholarly, social and material states of living of the worker and to diminish them from mechanical worries.

\section{A. STATEMENT OF PROBLEMS}

Manufacturing industry is the world's largest industry that employees the most large amount of human resources. The current trend in the industry is such that automobile industry is growing in a rapid way along with the development of the world. There are more number of man power is available in the company. The specialty of the company is the manpower cannot be substituted with any other professional except engineering. The role of manpower in the company is very critical. Recently manpower turnover is the biggest issue in the industry. This causes the productivity and performance of the company. The company works in its own way. When a new employee is appointed by the company it takes months of stress and strain to train the staff and make him suitable and adaptable to the purpose and operation of the company. But the sad part is the company appointing the employees temporary. The employees are aware that even though the company providing the good welfare measure still it not satisfied because of the standard of job.

Even though the company provide lots of welfare measure in some situation it is not worked out properly because of employee conflicts. In that situation the company wants to replace the employee to fill the vacant place. In this time company want train the employee again to replace the vacant area. Therefore the reason of the study isto find out how welfare measure are provided by the company and how the employees are satisfied with the company accommodation given to the employees which plays a very important role in the employee life.[6]-[10]

\section{OBJECTIVES OF THE STUDY}

To find out whether the employee is bringing out is whole individual talent to develop the work force of the organization. Encourage forums that promote employee well-being at the workplace and organize events.

Everything done for the betterment of the employee which denotes Welfare that should be comfortable and standard to the employee. .[11]-[15] 


\section{SCOPE OF THE STUDY}

EMPLOYEE WELFARE conveniences are exhaustive term including different administration advantages and offices offered to the worker's by the organisation.

1. To Develop and maintain motivation of workers by proving incentives.

2. To aid the self-development of employee at all the level.

3. To give chances to self-awareness and development and in addition gaining essential expertise and experience.

\section{Hypothesis for the Study:}

The accompanying speculations are set for the present examination:

1. H0: `Manufacturing Industries are sufficiently giving welfare measure offices

H1: Manufacturing ventures in are not sufficiently giving welfare measure offices

The work put conditions (Environment) is palatable in this businesses.

Statutory Welfare Facilities gave in this association isn't tasteful.

Non-Statutory Welfare Facilities gave in these assembling enterprises isn't agreeable.

Employee welfare office enhances - Work proficiency, Standard of leaving, Loyalty towards boss, High inspiration level and High Satisfaction level among the representatives. [16]-[20]

\section{NULL HYPOTHESIS:}

There is no critical distinction between age assemble as to factor affecting

Level of awareness towards protection and security issued in the Organization

There is no critical distinction between Gender with respect to factor impacting and influencing, level of mindfulness towards protection and security issues in the Organization.

There is no critical contrast between level of fulfilment in welfare measures and factors impacting and influencing the welfare measure. There is no huge distinction between level of fulfilment welfare measure and protection and security issues in Organization. [21]-[25]

\section{RESEARCH METHODOLOGY}

\section{A. Research}

Research is a circulation of finding the final result for the problem given, which will give solution for the future planning of the organisation.

The Research means "A particular enquiry is required for analysing the real fact in regarding to the any branch of knowledge."

\section{B. Research Methodology}

Finding the solution systematically for solving the problem which arises in the research is known as Research Methodology. Research methodology is based on the research design and the certain techniques allowed to expand the study.

C. The steps involved in descriptive study are as follows

$>$ The study must create the destination.

$>$ Identify the quantity of people to choose the sample.

$>$ Data collection procedure is adopted.

Analysing the information.

$>$ Conclude and suggest.

\section{Research Design}

Research Design is mainly used to find the solution to solve the specified problem with the gathered information created by the study unit. Thus examination configuration received to this investigation is clear research. Enlightening technique was embraced in light of the fact that it manages portrayal of the situation as it exists at display.

\section{E. Examining Techniques:}

Sampling process is undertaken by the researcher after collecting the data decision is done through the sample, a consideration.

\section{RESULTS \& DISCUSSION}

Review technique is considered will be viewed as the best strategy for information accumulation are survey Private individual Determine test estimate, the strategy used in the survey were gathered by the individual meeting. The poll comprise for the various inquiry includes both particular and general inquiry identified with representative welfare.

\section{A. Tools for collecting data:}

There are two types data gathered for the study. Collections of data are several types for finding appropriate data.

The researcher should understand while collecting the data there are two sources of data are available, that is Primary data \&Secondary data.

\section{B. Primary data}

Questionnaire method is used to gather the information from the employee. Primary data is the perfect survey method

\section{Secondary data}

Second source of information are gathered through study material, online and various journal, magazines etc.

\section{Statistical tool analysis \\ Percentage Analysis}

\section{E. Measurable Tools utilized Percentage Analysis}

In this investigation rate strategy test are utilized. The accompanying are the equation

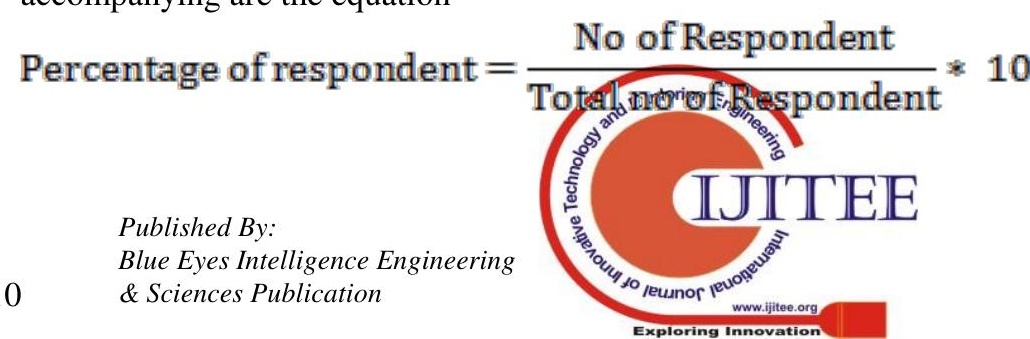




\section{REVIEW OF LITERATURE}

\section{A. Survey of Literature}

Survey of writing is an imperative perspective in any exploration ponders as it gives a profound comprehension of the examination issue and a very clear introduction to the scientists. Examiners get a reasonable feeling of centre by discovering what has just been done and the holes in the exploration considers. It additionally helps in moulding and controlling the examination a productive way by offering profound bits of knowledge and alternate points of view on the exploration theme.

SELVARAJ (1995): Has made an investigation with the goal of lessening the rate of mishaps and to enhanced mechanical conditions positively impact inspiration and assurance of the representative and will build their sense of duty regarding work

RBAN SINGH (2001): The investigation manages workplace inside the processing plant. The examination made infers that the hardware inside the processing plant ought to be kept flawlessly cleaned and fenced legitimately which would maintain a strategic distance from mishap.

\section{FINDINGS}

1. Majority of the respondent is $(31 \%)$ viewed that the welfare council is assembled once in a year.

2. Majority of the respondents (39\%) feels that the free safety equipment provided by the concern is good.

3 . $(39 \%)$ of the respondents feels that the company provide secured canteen.

4. $40 \%$ of the respondents feel that safety slogan contest in conducted through the concern.

$5.39 \%$ of the respondents are highly satisfied with the medical inspection.

$6.42 \%$ of the respondents agreed that the inspection reduce industrial accidents.

7. Majority of the respondents feels that the company provides maternity leave for the female employee.

$8.78 \%$ of the respondents feels that work based accidents is due to unsafe material handling.

\section{SUGGESSTIONS}

The Company's medical facility is very good. But the Organization may also improve the medical facilities according to employee's needs.

The Company should create awareness about the safety measures through posters, slideshow because it reaches the employees quickly and easily understandable even to uneducated people also.

The administrative setup is to supervise the welfare scheme are comfortable in the company. The company may also arrange Conference and meeting to know the effectiveness of supervision to the employees. relations. The investigation has discovered that the working

The Company has to provide safety measures and awards to motivate the employees.

Overall welfare measure is very good. So the company is highly concentrating with the employee welfare.

The company should follow more preventive policies in order to reduce the accidents occurring in the work place.

Safety committee should be conducted properly every month in the company for the benefit and awareness of safety to the employee.

\section{CONCLUSION}

This study would be helpful for the company and also to improve some welfare and safety activities inside the company. The strength of any organization depends entirely on effective and efficient working of all the employees. The management should take special care to frame certain policies procedures to improve the welfare and safety measures of the organization.

The study concluded that the employee welfare measure plays very important role especially in manufacturing company. The management should give importance for welfare measure equal to their objectives. Employee welfare is one of the main tools for achieving goals for the company. So the company should provide maximum facilities which should be beneficial to the employee.

\section{REFERENCES}

1. Vasanthi, S. \& Rabiyathul Basariya, S. 2019, "Influence of value analysis and cross training in industry", International Journal of Engineering and Advanced Technology, vol. 8, no. 6, pp. 1810-1811.

2. Velvizhi, R., Sri Gowtham, S. \& Jeya Priya, D. 2019, "Examination of early feedbacks for effective product retailing on E-commerce websites", International Journal of Engineering and Advanced Technology, vol. 8, no. 6 Special Issue 2, pp. 703-706.

3. Anuradha, C., Pothumani, S. \& Kavitha, R. 2019, "A novel method towards E-commerce", International Journal of Engineering and Advanced Technology, vol. 8, no. 6 Special Issue 2, pp. 535-538.

4. Thomas, J. \& Rabiyathul Basariya, S. 2019, "A study on the issues of financial ratio analysis", Indian Journal of Public Health Research and Development, vol. 10, no. 3, pp. 1079-1081.

5. Ramachandran, S. \& Rabiyathul Basariya, S. 2019, "Online marketing - study on customer satisfaction and relationship", Indian Journal of Public Health Research and Development, vol. 10, no. 3, pp. 1072-1078.

6. Priya, R., Vinothini, G. \& Cor Jesu, C.D. 2019, "The mentor-protégé relationship for professional growth", Journal of Advanced Research in Dynamical and Control Systems, vol. 11, no. 9 Special Issue, pp. 1110-1119.

7. Jannifer Rani, N., Bina Pani, S. \& Nimisha, N.S. 2019, "A study on money back polices available in LIC", Journal of Advanced Research in Dynamical and Control Systems, vol. 11, no. 9 Special Issue, pp. 833-839

8. Saillaja, V., Jhansi Rani, K. \& Catherine, R. 2019, "Global marketing management planning and organization", Journal of Advanced Research in Dynamical and Control Systems, vol. 11, no. 9 Special Issue, pp. 489-493.

9. Saillaja, V., Jhansi Rani, K. \& Catherine, R. 2019, "The new phase of marketing information system", Journal of Advanced Research in Dynamical and Control Systems, vol. 11, no. 9 Special Issue, pp. 482-488.

10. Thoufiqulla \& Raju, D.V. 2019, "Perception of indian investor towards investment in mutual funds with special reference to mip funds", Journal of Advanced Research in Dynamical and 
Control Systems, vol. 11, no. 5, pp. 177-183.

11. Jasmine, K.R.M. \& Basariya, S.R. 2018, "A study on the customers benefits on mutual funds", International Journal of Civil Engineering and Technology, vol. 9, no. 4, pp. 45-48.

12. Vasanthi, S. \& Basariya, S.R. 2019, "Pros and cons of on the job training versus off the job training", International Journal of Scientific and Technology Research, vol. 8, no. 10, pp. 671-674.

13. Pavithra, J. \& Ganesan, M. 2016, "A study on awareness and impact of micro-financial schemes", International Journal of Applied Business and Economic Research, vol. 14, no. 8, pp. 5449-5460.

14. Pavithra, J., Dilli Babu, P. \& Ambuli, T.V. 2014, "A study on budgetary control at Maruti Service Masters, Chennai", International Journal of Applied Business and Economic Research, vol. 12, no. 2, pp. 151-161.

15. Gunaraja, T.M. \& Venkatrama Raju, D. 2018, "Determining factors of organisational climate with reference to leadership styles", International Journal of Mechanical Engineering and Technology, vol. 9, no. 9, pp. 1327-1332.

16. Gunaraja, T.M. \& Venkatrama Raju, D. 2018, "The role of job satisfaction and training of employees in determining organisational climate of a selected industry", International Journal of Civil Engineering and Technology, vol. 9, no. 8, pp. 1266-1269.

17. Aarathy, T.S. \& Raju, D.V. 2018, "Performance appraisal and its effects on employees with respect to it sector in Chennai city", International Journal of Civil Engineering and Technology, vol. 9, no. 6, pp. 1535-1538.

18. Aarathy, T.S. \& Raju, D.V. 2018, "Employee perception towards performance appraisal system in IT sector", International Journal of Mechanical Engineering and Technology, vol. 9, no. 5, pp. 131-135.

19. Porselvi, W., Jublee, D. \& Sivanesan, G. 2018, "A study on factors influencing adoption of technology and innovation in banking industry, tamilnadu, India", International Journal of Mechanical Engineering and Technology, vol. 9, no. 5, pp. 789-800.

20. Akessa, G.M. and Dhufera, A.G., 2015. Factors That Influences Students Academic Performance: A Case of Rift Valley University, Jimma, Ethiopia. Journal of Education and Practice, 6(22), pp.55-63.

21. Miller, G. and Shih, C.C., 1999. A faculty assessment of the academic rigor of on-and off-campus courses in agriculture. Journal of Agricultural Education, 40, pp.57-65.

22. Tsinidou, M., Gerogiannis, V. and Fitsilis, P., 2010. Evaluation of the factors that determine quality in higher education: an empirical study. Quality Assurance in education, 18(3), pp.227-244.

23. Farooq, M.S., Chaudhry, A.H., Shafiq, M. and Berhanu, G., 2011. Factors affecting students' quality of academic performance: a case of secondary school level. Journal of quality and technology management, 7(2), pp.1-14.

24. Fitsilis, P., Gerogiannis, V. and Anthopoulos, L., 2014. Ontologies for software project management: a review. Journal of Software Engineering and Applications, 7(13), p.1096.

25. Adams, J.D. and Jaffe, A.B., 1996. Bounding the effects of R\&D: an investigation using matched establishment-firm data(No. w5544). National bureau of economic research.

\section{AUTHORS PROFILE}

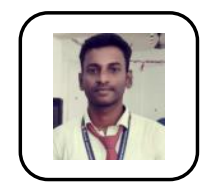

G. Santhoshkumar, Assistant professor, Department Of Science \& Humanities, Bharath Institute of Higher Education and Research ,Chennai, India. .

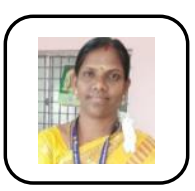

R. Velanganni, Assistant professor, Department Of Science \& Humanities, Bharath Institute of Higher Education and Research ,Chennai, India

S. Robin, Assistant professor, Department Of Science \& Humanities, Bharath Institute of Higher Education and Research ,Chennai, India 